\title{
Björk on the Gallows: Performance, Persona, and Authenticity in Lars von Trier's Dancer in the Dark
}

\author{
Pascal Rudolph \\ University of Potsdam \\ pascal.rudolph@uni-potsdam.de
}

\begin{abstract}
In Dancer in the Dark (2000), Icelandic popstar Björk portrays the main character of Selma. Lars von Trier, the director, described his film as an exercise in emotionally manipulating the audience. Drawing on Philip Auslander's concept of the "musical persona", this study argues that the decision to cast a popstar, in combination with the structure of the film, serves von Trier's purpose of intensifying the film's manipulative potential, by evoking an impression of shocking realism or authenticity. This study furthermore places the presentation of the filmic character in conversation with Björk's popstar status, critical reception of the film, as well as reception of her performance within it. Extending Auslander's concept of persona through a transmedial approach provides new perspectives on Björk's performance, Dancer's polarized reception, and analytical models for performers' public reception.
\end{abstract}

KEYWORDS: Popstars in Film, Musical Persona, Transmedia, Björk, Dancer in the Dark, Lars von Trier

\section{Introduction}

In the first scene of Lars von Trier's Dancer in the Dark (2000), the audience observes a rehearsal for a local amateur production of The Sound of Music. One actor complains to Samuel, the director, about the lead performer Selma, played by Icelandic popstar Björk: "You sure you think she's good enough for the part? Her singing's very strange, and she can't dance." Samuel answers: "Oh, come on, it's the first time she's tried it. She just has a particular way of approaching the song. Sure, it's not perfect, but Selma has everything our Maria needs. She's a natural." (von Trier 2000: 2) (1). This dialogue encapsulates not only the public response to 
the film, but also the critical reception of Björk's performance: perceived as her acting debut, international critics reviewed her portrayal of Selma as authentic, sincere, and natural. Yet, critics remained divided about the overall film: "Reviled as a failed experiment, hailed as a masterpiece, it's hard to believe that any one film could yield so many different and passionate responses" (Kaufman 2003: 153; see also Rosenbaum 2000; Elbeshlawy 2016: 71). According to Jack Stevenson (2002:163), the film "might well be the most polarising film ever made," for despite its financial success and prizes it secured, some respected critics labelled the film "psychological snuff" and "emotional pornography" (ibid.: 159). The controversy itself drove publicity:

For the first time in the history of American entertainment magazine Entertainment Weekly, the film received reviews printed side by side by both the magazine's film critics. While Lisa Schwarzbaum considered it "astonishing and triumphant", Owen Gleiberman described it as "a crock". (...) Some distributors attempted to capitalize on the controversy, while the UK based Film Four Distributors actually offered spectators a full refund if they left the film within its first thirty minutes. (Ago 2003: 42).

Lars von Trier himself described his film as an exercise in emotionally manipulating the audience (cf. filmmaker commentary on the NTSC edition of the DVD; von Trier 2000: vi; Björkman 2001: 243, 249). Torben Grodal concludes that Dancer's narrative simplicity resulted in the impression of Selma as "the blind girl-tragedy to outperform the most tear-jerking, blind girl-films ever made, as well as the most unselfish mother ever to breathe" (Grodal 2004: 160; see also Tiefenbach 2010: esp. 64-134).

I posit that Björk's performance played a crucial role in informing the reception of Dancer, in tandem with the filming and editing processes employed by von Trier, such as extreme close-ups, and pseudo-documentary affectations like utilizing handheld cameras. Analyzing through this equivocal gaze, Ahmed Elbeshlawy (2016) recently argued that "Björk created an onscreen woman character quite alien to the category of the cinematic": (2016: 71) an "anti-cinematic figure" (ibid.: 77). Utilizing Philip Auslander's concept of the "musical persona", I argue that the casting of a popstar, in combination with the narrative structure, increased the film's impression of shocking realism, perceived then as authenticity. To do so, I apply a transmedial approach (see Hansen 2019) by placing Björk's role as a popstar in conversation with her presentation as the main character in Dancer, as well as the reception of both the film and her performance in it. I follow Allan Moore here in acknowledging that "authenticity is ascribed to, rather than inscribed in, a performance" (2002: 220). Performed identities also constitute cocreations, since they always involve negotiation between performers and their audiences (Auslander 2006: 114-115). By understanding authenticity as located in the agreement between the audience and the performer, we shall see that the film's director, the actors, and the discourse surrounding the film intentionally blurred real life and fiction. I suggest that the exceptional construction of Björk's performance in the film stems from her role as not only the main character, but as composer for the filmic music, and the subsequent performance of her real-life musical persona therein. Dancer marks an extreme in this regard, as "one of the boldest and least-conventional film projects to have featured a star pop performer" (Cooke 2008: 419). I therefore propose that Dancer raises fundamental questions not only with regard to the integration and interaction between popstar personae 
and fictional filmic characters, but also the debatable differentiation between musical and film acting performances, as well as conceptual tensions between artificiality and authenticity.

\section{Dancer in the Dark: A Brief Overview}

Selma Jezkova (Björk), a single mother and Czechoslovakian immigrant in Washington State, lives with her son Gene (Vladica Kostic) in a trailer behind the house of her landlord and friend Bill Houston (David Morse), a local policeman, and his wife Linda (Cara Seymour). Selma's secret is a hereditary disease that will make her go blind, and will also strike Gene, unless she pays for an operation for which she works overtime. Selma's only pleasures are watching musicals and rehearsing in the local amateur production of The Sound of Music, accompanied in both by her maternal friend Kathy (Catherine Deneuve). Because of Selma's increasing blindness, she loses her factory job and her role in the musical. One night, Bill confides to Selma that he is debt-ridden and afraid of losing his spendthrift wife Linda. Following a logic of quid pro quo, she tells him about her illness and the money she is saving for Gene's operation. After Selma refuses Bill's request for a loan, he steals her savings and tells Linda that Selma tried to grope him. When Selma confronts Bill to recover the money, he pushes her to kill him in suicidal despair. Selma retrieves the money and pays an oculist for her son's surgery. Refusing to defend herself or to reveal Bill's secret, she is found guilty of murder and sentenced to death. As Selma's world metaphorically and literally grows dark, she escapes into daydreams about living in a musical. Selma's intensely distressing story is intercut with alternating sequences of musical performance in which the characters suddenly obey the rules of a Broadway show.

\section{Selma: Dream Double versus Fictional Reality}

The film possesses a dualist structure contrasting its fictional reality (the external world) with Selma's imagination (her internal world, via the musical numbers). Although the external narrative triggers and provides rhythm to the musical numbers, none of the film's characters except Selma seem affected by the musical numbers when they conclude. The external and internal worlds differ in several aspects: whereas von Trier audiovisually characterizes the external world with colder colors, a shaky camera, and monaural sound, the internal musical sequences feature brighter colors, numerous cuts between up to 100 static cameras, as well as stereophonic sound featuring the dubbed voice of the main character, an orchestral score, and dancing ensembles. As her circumstances deteriorate, Selma's internal world disintegrates: these components that make up her internal world's increased production values progressively disappear. As a result of their disappearance, the musical numbers become increasingly diegetic, and their performances more anchored in the narrative.

This dualist structure reflects the character of Selma. For external Selma, all men seem irrelevant. There is no information given about her son's father and she displays no sexual attraction. Linda Badley reads her performance as asexual: "uninterested in sex, she sublimates desire into relentless work and refuses her dogged suitor Jeff" (2010: 88). Rather, Selma is "stubbornly self-sufficient, insisting she has no use for a man" (ibid.: 87). When Jeff asks Selma whether he can give her a lift, she answers: "I don't want a boyfriend, I told you" (dir. von Trier 
2000: 0.27.50). The final shot of the film clarifies the intent of this performed repression: as the film's only use of a camera crane, the upwards movement of the camera's perspective upon Selma's death suggests religious aspects to her sexual innocence in the face of her woes, such as immaculate conception and apotheosis. The number "I've Seen It All" concludes, conversely, with Selma driving away from Jeff atop a train compartment bursting with men. Even when Jeff visits her in prison and confesses his love, she seems unable to answer (ibid.: 1.57.00). In contrast, the second part of the song "In the Musicals" begins with Selma's question "Why do I love you so much?" to Oldřich Nový (ibid.: 1.34.14), who functions as a male personification of Selma's conception of musicals. Selma's fantasy double seems more capable of interpersonal connection, since she performs "a range of intense and compelling emotions, expresses her sexuality as her body responds pleasurably to the sound she is producing, and projects a sophistication, intelligence, and energy that drains from her elsewhere in the film" (Sjogren 2006: 191). Apathetic and asexual in the external narrative, she becomes "the center of attention, a diva with a majestic (rather than 'funny') voice" (ibid.: 191) in her musical world. These differences between Selma and her dream double grow particularly striking in the second half of the film: although externally Selma diminishes into a more hushed and paralyzed woman, blind and impassive, internally she sings and dances, even as her imagined world visually and musically disintegrates for the spectator.

Comparing "In The Musicals" and "107 Steps" with their narrative frames provides stark evidence of this contrast. Just before the second half of "In The Musicals," the film diverts the audience's attention to the external lawsuit, involving several testimonies from Selma's former friends. During Nový's testimony, only the sketching sound of a court artist behind her seizes her attention, and so triggers her internal world, in which she not only sings and dances, but also performs a tap dance with Nový. Before the number "107 Steps," Selma waits for her execution, absolutely paralyzed. When it is time to walk the 107 steps to the execution hall, she suffers a collapse and cannot walk, much less get up from her bed. Only the help of a friendly prison guard, providing her a rhythmic trigger from the sound of their steps ("I give you something to listen to," dir. von Trier 2000: 2.01.41) allows her to escape into her fantasy world, in which she finds herself able to dance to her execution.

The audiovisual dualism of Selma's internal and external worlds hint at an intentional effort to generate tension between the audience's interpretation of Björk as Selma's actor versus Björk as her self-same popstar persona, a semiautobiographical self-insert.

\section{It's Oh So Björk: Björk as a Popstar}

Despite the album Björk (1977), her second solo album was titled Debut (1993) to emphasize the idea that this was her first genuinely solo recording project. Debut sold widely, successfully redefining Björk's solo image:

The music videos and cover art for Debut were to define her image for years to come: the cover art by photographer Jean-Baptiste Mondino presents Björk in vulnerable, retiring pose; and the animation-like style of the video for "Human Behaviour", the first single from the album, projects a child-like Björk in surreal surroundings - a realization she reached with the then little known director Michel Gondry. (Dibben 2009: 16). 
Here already we find attributes like "vulnerable," "retiring," and "child-like," which as we shall see also apply to her performance as Selma. Considerable previous research deals with this public image. The image and persona Björk created through and across her performances appear overtly autobiographical. In her monograph Björk, Nicola Dibben analyses how Björk realizes the emotional authenticity and intimacy which she appears to offer audiences through "her mediated public presence in images, journalistic reporting, and 'behind the scenes' style documentaries" (2009: 154; see also Dibben 2006). Marion Leonard (2007: 82-86) explains that British journalists depicted Björk as a "little pixie," through their use of patronizing and particularly gendered language. Daniel Grimley examines how Björk's song "Hidden Place" (One Little Indian Records 2001) constructs an authentic and intimate sense of expression via her slightly over-miked voice and the "representation of landscape [which] relies (...) upon the complex layering of textures whose timbral character suggests a particular affective quality" (2005: 4445). "Hidden Place" was originally planned to be one of the songs in Dancer. Furthermore, "Hidden Place" and the music in Dancer share many common features, such as the song's "scratchy vinyl quality" (Grimley 2005: 45), much like in "Scatterheart" from Dancer, wherein the sound of a record player both accompanies and initially triggers the song. The drum'n'bass sound of "Hidden Place" also suggests heartbeats (ibid.: 47), while Selma's audible heartbeat triggers and accompanies "Next To Last Song" in Dancer. The song's music video (dir. Inez van Lamsweerde and Vinoodh Matadin 2001) intensifies the impression of authenticity and intimacy by showing Björk apparently nude and without make-up in extreme close-up shots panning around her face. The constructed image of authenticity for Björk the popstar relates closely to her performance in the film, and the character of Selma.

In order to understand this construction better, consider Björk's biggest musical hit. In 1995, the music video for "It's Oh So Quiet" arrived on television broadcasts, "the perfect Björk single, albeit she didn't write it herself" (Aston 1996: 305). "It's Oh So Quiet" covers Betty Hutton's recording (RCA 1951), itself a cover of Horst Winter's "Und jetzt ist es still" ("and now it is quiet"; Austroton 1948). Although one may draw parallels between Björk's performance in Dancer and other songs or albums (e.g. the use of micro-beats in her album Vespertine [One Little Indian Records 2001]), "It's Oh So Quiet" provides a useful starting point for understanding how audiences may have integrated the conception of Björk as a popstar. For one, the song's release before Dancer and its overwhelming popularity (Dibben 2009: 17; Pytlik 2003: 100-101) speaks to the historical stance towards Björk's public image, an image which has since changed from child-like to the more current interpretation of cyborg (2).

As Patricia Pisters notes, the music video "pays homage to the classic Hollywood musicals" (2003: 134). Björk's performance of this song clearly draws inspiration from Betty Hutton herself. By adapting Hutton's over-the-top persona in "It's Oh So Quiet," Björk alludes to the American musical theatre actor. The music video similarly evokes Jacques Demy's musical film Les Parapluies de Cherbourg (1964) by employing similar décor (the gas station and the garage) and dance props (the umbrellas). Henry Keazor and Thorsten Wübbena (2007: 283) detect a cinematic quotation in the music video's overhead shot of the umbrellas, which not only refers to the title of Demy's film, but also to the visual design of the opening credits, which display umbrellas from the same unusual camera angle. Furthermore, Catherine Deneuve, who plays Kathy in Dancer, achieved her initial popularity as an actor 
with her performance in Les Parapluies. This intertextual network proves only more complex upon closer examination of the music video.

The song features two alternating sections, a quiet one and a louder one with the sudden inclusion of a brass band. Director Spike Jonze describes his understanding of the song as "the verse being the real world and the chorus being her fantasy" (quoted in the DVD booklet of The Work of Director Spike Jonze [Palm Pictures 2003]). The visual arrangement evokes von Trier's later film: while people act normally in the background during the quiet verse, they suddenly transform, singing and dancing Broadway-style routines during the louder chorus, the latter including Björk tap dancing similarly to Selma's tap performances in Dancer. The camera movements in the choruses also change to more dynamic motion (including swish pans), contrasting the slow-motion tracking shots of Björk during the verses (Rosiny 2013: 190). On top of this, there is a slight color shift from colder colors (verse) to brighter colors (chorus).

Many audience members of Dancer in 2000 would have had ample reason to remember Jonze's music video for "It's Oh So Quiet." The music video for Björk's hit "It's Oh So Quiet" is an homage to classic Hollywood musicals and cites Jacques Demy's musical film Les Parapluies, in which Catherine Deneuve had her breakthrough. In making a melodrama/musical film that casts Björk as the main character and Deneuve as Selma's maternal friend Kathy, as well as constructing a dualist structure that contrasts fantasy and real worlds arranged in a visual style similar to that in Jonze's music video, von Trier inserts Dancer into an existing intertextual network.

\section{Björk as Selma: Aspects of the Film's Production and Public Reception}

In analyzing the production and public reception of Dancer, the prevailing critical opinion suggests that viewers tended to understand Björk's performance as blurring the boundaries between acting and wholly transforming into a film character, between fiction and reality, and between Selma and Björk. Given the preceding discussion, it is unsurprising that von Trier invited Björk to compose the film music for Dancer after he saw the music video for "It's Oh So Quiet" (von Trier quoted in Koplev 2003: 188-189; Dibben 2009: 19). Although Björk hesitated a long time once von Trier asked her to consider additionally portraying the main character, she finally agreed: "Lars, the director, convinced me that the only way to completely complete the music, was if the person who wrote the songs would also be the main character in the film. He convinced me that it was an extension of my songs" (Björk 2000).

Although the generally accepted critical narrative contends that Björk made her acting debut with von Trier, she was already active as an actor. She acted in the Icelandic made for television film Glerbrot (dir. Kristín Jóhannesdóttir 1987) and in the Icelandic drama film The Juniper Tree (dir. Nietzchka Keene 1990). These were likely forgotten because the projects predated Björk's international musical stardom, had extremely low budgets, and did not receive critical attention as a result. Nevertheless, Björk already had acting experience, even if the discourse surrounding Dancer contends that she did not. After Dancer, Björk only acted on film in her then-partner's experimental Drawing Restraint 9 (dir. Matthew 
Barney 2005). For mainstream critics, however, Dancer was to be her first and last appearance as a film actor.

During the making of the film, promoters focused on the fierce struggle between von Trier and Björk during their collaboration: "the battle over Selma became Dancer's popular hyper/subtext," as Badley puts it (2010: 89; cf. Stevenson 2002: 152-154). "Von Trier accused her of eating her costume. She [Björk] recently charged her director with being an 'emotional pornographer'" (O'Sullivan 2000). Lars von Trier complained that they "had the worst possible times together" (quoted in Koplev 2003: 186). This battle found its climax with Björk's temporary boycott, even consulting legal counsel in an attempt to void her contract (see Lössl 2000; O'Sullivan 2000) (3). As she and the director claimed in interviews, and the prevailing narrative with which the studio promoted the film, Björk transformed more and more into Selma. Rather than the killing of Selma, the argument seemed to be about killing herself (Tate 2000; Grissemann 2006; Heath 2011):

As the shooting wore on over the summer of 1999 in Avedøre and in Trollhättan, Sweden, the two [Björk and von Trier] battled over the soul of Selma. And perhaps as a way for Björk to wrestle her away from Lars, she became Selma... but too completely, without the distance a professional actor brings to the task, without the ability to leave the set at the end of the day and think about something else. When Selma, for example, was about to shoot her friend, officer Bill, Björk herself had a nervous breakdown. (Stevenson 2002: 149; his emphasis).

Björk's own statements about her experience on the set support this supposed authenticity and transformation. Even while she collected several awards, such as the Best Actress Award at the 2000 Cannes Film Festival and the European Film Award, and was nominated for the Golden Globe Award, she dissociated herself from acting and negated her role as an actor: "I understand the ground qualities of a person who is born an actor, and I don't think I have those" (quoted in Tate 2000). She continued:

It was all improvised. Lars said I couldn't learn the lines by heart, so... I would just know, "O.K., I'm going in this room." Sometimes I would know what would be said to me, and sometimes I wouldn't. We'd just do it, and I'd react instinctively to all the situations. Quite often I'd do something he didn't expect at all. The good thing was I'd been Selma for so long that it was usually right, and it was more Selma than Björk. (...) Afterward, talking to a lot of actors since, I realized it was probably the most spontaneous film ever shot. (Björk quoted in Tate 2000).

Lars von Trier highlighted Björk's emotional performance accordingly: "It's an incredible performance. And it's not acted, I must say that, it's not acted, it's felt" (DVD interview, Zentropa 2001). Many critics shared this impression, including Paper's critic Greg Tate (2000) who claimed that "Björk performs Björk." According to PopMatters' film writer Lucas Hilderbrand (2000), "Björk doesn't shed her 'musician' persona, but rather complicates her own mythology with this character's tragic circumstances." He continued: "because Björk wrote the songs, they sound like Björk's other work. So the film reads, for Björk fans (...), as if Björk is experiencing Selma's plight" (ibid.). Professor of film studies Linda Badley even drew parallels between Selma's and Björk's biography: "Having worked in fish 
packing and Coke bottling plants and, in a widely publicized incident, assaulted a journalist who had approached her ten-year-old son, she identified intensely with Selma" (2010: 90). Similarly, Entertainment Weekly's Journalist Lori Reese maintained that von Trier

has said that the "Dancer" screenplay was partly inspired by its leading lady. He was intrigued by Björk's Spike Jonze directed video for "It's oh so Quiet," in which the singer portrays an everyday person who is entranced by musicals, much like Selma is in the film. Moreover, he based several key parts of the screenplay on press coverage of Björk's life - particularly the singer's now famous fracas with a TV reporter who tried to interview her 14 year old son without permission. "I lost my temper and beat this woman up," Björk recalls. "Lars talked quite a lot about that, because I'm normally a very peaceful person. When someone is driven that far beyond all lines and then explodes, it's a different kind of explosion." In "Dancer," Selma is driven to a similarly brutal act while trying to protect her son. (Reese 2000).

Here we can see that the reception constructed a tripartite relationship between Björk's Selma, "It's Oh So Quiet," and Björk's private life. According to Badley, the supposed overlap between Selma and Björk leads to a finale in which fiction and reality are no longer separable:

Selma cannot be distinguished from Björk, as the [execution] scene has been described by cast and crew members as "real" trauma and judged both as award-worthy acting and as completely unprofessional. Was it even a performance? As in the most disturbing scenes in [von Trier's] The ldiots, the borders between reality and simulation, performance and being, masochistic empathy and sadistic voyeurism collapse. We become witless witnesses of someone's real trauma, and the film ends in agonizing rupture. (Badley 2010: 98-99; emphasis Badley's).

But what is it if not a performance? Is it a failed performance? Can that failure explain the film's emotional impression on audiences?

\section{Persona and Character in Musical and Acted Performances}

To take a step back, then: who exactly is performing what? Here, I borrow Philip Auslander's concept of the "musical persona" in order to resolve this complication. For his performer-centered theory of musical performances, Auslander concerns himself with Lorraine Daston's and Otto Sibum's definition of persona as a recognizable cultural identity "intermediate between the individual biography and the social institution" (2003: 2-3). "Unlike actors, opera singers, or even ballet dancers," Auslander argues, "musicians normally do not portray overtly fictional characters in their performances" (2006: 117). Building equally on Simon Frith's Performing Rites (1996: ch. 9, 10; see esp. pp. 186, 212), Auslander identifies three layers of musical performances (2009: 305): the real person (Frith's "personally expressive strata"), the performance persona (Frith's "star personality"), and the character (which Frith calls the "song personality"), "an optional element that comes in primarily when the musician is a singer performing a song that defines a character textually" (Auslander 2004: 7). The musical performance becomes a presentation of identity, a musical persona which all musicians portray independent of their star status (Auslander 2015b: 318). Auslander defines the persona as 
a performed identity that is not a fictional character such as those portrayed by actors. It is presentational rather than representational (or at least is perceived that way) and often takes the form of a self-presentation on the part of the performer. Although the audience may believe this self-presentation to constitute the performer's identity as a human being (this is particularly true in such realms as stand-up comedy and popular music), it is crucially important to understand that it is a construct designed to allow the performer to work within specific aesthetic, genre, social, and cultural frames and discourses. (Auslander 2015a: 76).

Auslander pursues the idea that "a persona is an identity that can be performed directly and for its own sake rather than as an intermediary between actor and character" (2015a: 67). The persona can therefore be understood as the direct object of the verb "to perform," such that personal identities become performative constructs (Auslander 2006: 102). Since Auslander understands musical performances as self-presentation, he adopts Erving Goffman's taxonomy for describing how one performs personae (cf. Auslander 2006: 103-118). Goffman (1956: 13) uses the term "front" for "that part of the individual's performance which regularly functions in a general and fixed fashion to define the situation for those who observe the performance." He discerns three standard parts of front: setting, "involving furniture, décor, physical lay-out, and other background items which supply the scenery and stage props for the space of human action played out before, within, or upon it" (ibid.: 13); appearance, describing "stimuli which function at the time to tell us of the performer's social statuses" (ibid.: 15); and manner, referring to "those stimuli which function at the time to warn us of the interaction role the performer will expect to play in the on-coming situation" (ibid.: 15).

Goffman (ibid.: 13) defines performance as "all the activity of an individual which occurs during a period marked by his continuous presence before a particular set of observers and which has some influence on the observers." In contrast to broader conceptions of persona that identify personae as transmedial phenomena (see Hansen 2019) this study focuses on the consequences of persona as a specifically corporeal presence in concrete performances. Performance certainly includes more than the concert stage. Musicians also perform their personae through recordings, interviews, photos, documentaries, films, and other media. This presence is indeed informed by various media texts. But to me, the term 'image' encompasses better the transmedial phenomenon that informs the reception of some personae. While a performer's image represents the enduring, collective transtextual and transmedial construction of an individual, image emerges only as this collective across different media texts, to resolve the question: who do we think constitutes this particular performer? This study instead suggests that personae more narrowly refer to what is performed through media texts.

As a part of this image, the idea of a "real person" is crucially important to the performance's meaning for the audience. At the same time, insistence on the "real person" introduces problems for broader understandings of how the image functions, as the concept implies an attempt to essentialize the performer. According to Auslander, the

real person is the dimension of performance to which the audience has the least direct access, since the audience generally infers what performers are like as real people from their performance personae and the characters they portray. Public appearances offstage do not give reliable access to the performer as a real person since it is quite likely that interviews and even casual 
public appearances are manifestations of the performer's persona rather than the real person. (Auslander 2006: 5-6).

Here Auslander pushes against the boundaries of broader and narrower understandings of personae. Yet Goffman shows that every social interaction can be described and understood in terms of theatrical performances, such that the term "real person" may appear misleading. Indeed, the central argument of his book is that we all play-act, even when we absolutely "believe" in the part we are playing (Goffman 1956: 10-13). Following from Goffman, then, there is no need to suggest any intrinsic opposition between the presentation of self and a fictional character. Instead, every presentation of self can be understood to include a degree of theatricality, or even fiction. The "real person" is not revealed, but rather, performed. Moreover, the star system tends to package the biographical personality of the performer as a collectively accessible image (Borgstedt 2008: 133). The audience knows performers as private individuals only through this medially constructed form. Beyond that, the audience has no access to the private identity of a performer (Frith 1996: 215; Auslander 2009: 306; Moore 2012: 125-127) (4). Performers clearly enact personae if the audience does not know them and they function even when they remain invisible, much like pit musicians (Auslander 2015a: 68-69). At the same time, to understand the star system requires an understanding that audiences perceive personae in terms of things they know about the performers, or what they believe they know, as mediated through popular culture. While the pursuit of the "real person" behind the celebrity façade, that is, the concept of a "real person" behind the artist's mask is extremely important for contemporary western popular culture, it is equally important to stress its constructed nature (see Meyers 2009; Dyer 2012: 81-88; Jacke 2013). Whereas the "real person" describes a public idea of the artist as a "real" human being, or their "backstage" sensibilities constructed by audiences transtextually and transmedially, the "performer" points to the agency of a particular human being primarily as a category for discourse analysis. Similar to Michel Foucault's (1977:123) "author function," this category "serves as a means of classification" only so we can distinguish its "different forms of relationships among texts".

It is clear that the relationship between these categories is characterized by a reciprocal interdependence: all these categories inform and shape public perceptions of one another. These are dialectical tensions, since audiences interpret performances of persona and character not only vis-á-vis perceptions of the performer's image, but also their idea of the performer's "real person." At the very same time, these performances give form to the performer's image and shape our construction of them as a human being with feelings, intelligence, beliefs, experiences, and values. The image can therefore be understood as an umbrella term that hangs over the different elements of an artist, namely, that when a persona appears nearly identical with our idea of a performer as a "real person," what arises is an emotionally authentic image.

Auslander's demarcation between the persona and the fictional character performed by actors, as well as the focus on musical performances, does not mean that he suggests an opposition between acting and musical performance. Just as the performance of a musical persona does not necessitate the exclusion of a fictional character in a song, the performance of a fictional character in a film does not require the exclusion of an actor's persona. Analyzing the Brechtian actor and the Wooster Group, Auslander (2002 [1986]; see also 1992: 125-167) extended the actor/character dyad into a triad, in which the actor's persona presents a "fictional creation" to serve the needs of the performance (2002: 56-57). The persona "resides 
in an ambiguous middle ground between fiction (character) and reality (actor)" (Auslander 2015a: 65). In contrast to authors, painters, and composers, the musician and the film actor share their necessarily corporeal presence in their performance, even if their work is conveyed through other media. The performativity of the star provides a focal point for the aesthetic experience of the audience (Reckwitz 2019: 253). Since at least the development of method acting in the 1940s - in which the actor builds on experiences and emotions from their own life - "performing a scripted character" and "performing a version of the self" were conceptually intertwined in public imagination (cf. Gledhill 1991: 223). As early as 1948, Helmuth Plessner wrote:

Der Film bringt es zur Illusion des Schauspielers, der sich selbst verkörpert. Deshalb kann eigentlich nur hier die Rolle zum bloßen Vorwand und Hilfsmittel der Darstellung einer Person werden. (Plessner 1982: 406).

("The film contributes to the illusion of the actor who embodies himself. Therefore it is only here that the role can become a mere pretext and means for the depiction of a person.") [translation by the author].

"The star," as Edgar Morin (1960: 37) notes, "is not only an actress. The characters she plays are not only characters. The characters of her films infect the star. Reciprocally, the star herself infects these characters." Regarding stage actors, David Graver describes one form of the actor's corporeal presence as "personage (...) an aura generated by the public circulation of stories about the actor" (1997: 226). Much like Auslander, Graver insists that the status of personage is not the same as the "real person," but rather a way of "representing oneself within a particular discursive domain" (ibid.: 227).

Of course, there remain differences between acting and musical performances. Whereas the actor's persona normally mediates between actor and character (Auslander 2015a: 64), the musical persona is normally performed directly by musicians, that is to say, unmediated by a character (Auslander 2006: 117). Correspondingly, musical personae tend to be more static than actors' personae, as the latter may be those of a performer known for transforming themselves completely into their roles. Understanding authenticity and fictionality (or theatricality) as poles along a continuum, audiences appear prone to perceiving musical performances as tending towards one direction (musicians perform versions of themselves) and acted performances as tending towards the other (actors present fictional characters). We can destabilize these perceptive tendencies (placing static versus flexible, authentic versus fictional) by reconsidering the flexible and theatrical personae of musicians such as David Bowie or Lady Gaga, when contrasted with the narrower range or even individual filmic characters played by typecast actors like Adam Sandler (as the aggressive man-child) or Dwayne 'The Rock' Johnson (as the strong, infallible and ever-victorious action hero). These examples in particular blur the boundary between character and persona, as it is not entirely clear whether Sandler foremostly performs his persona, rather than a series of fictional characters who resemble one another, or whether Bowie performs fictional characters rather than a stable of significantly different personae.

Indeed, persona and character are closely related in film acting performances, and the characters portrayed by an actor are more involved in the performance of a film actor's persona and construction of her/his image when compared with the optional song characters in the performance of the musical persona, much less in the corresponding construction of the musician's image. Auslander (2006: 102) 
notes that what "musicians perform first and foremost is not music, but their own identities as musicians, their musical persona". I would add here that what a film actor performs is not exclusively a fictional character, but also her/his own identity as an actor - her/his actor's persona. Both the musical persona as well as the film actor's persona can be understood as "a performed presence that is neither an overtly fictional character nor simply equivalent to the performer's 'real' identity" (Auslander 2006: 102).

Thus, the persona provides a vehicle that allows us to compare more accurately what performers portray through acting and musical performances. I contend that this concept allows for a better understanding of Björk's performance in Dancer. Given her established image as the authentic popstar Björk and her previous absence from mainstream film, this image probably biased the aesthetic experience of the audiences. For that matter, the film credits her only as her stage name "Björk" rather than her full name. Indeed, every recognition of a star performer on screen involves a burst of transtextual activities, but as Ben Winters notes, "actors rarely perform as actors in an [sic] metafictional way in the same way as musicians or musical stars" (2014: 34; emphasis Winters'). Ordinarily, the aforementioned difference between acting and musical performances remains when musicians appear in a film:

more often than not, the on-screen musical performer [i.e. the classical musician in a narrative film] is functioning differently from his/her fellow actors. Unlike them, s/he may not even be playing a fictional character, but a version of themselves (...) and, as such, s/he is often engaging in the very activity that defines their "star" quality, namely musical performance. (Winters 2014: 18).

Audiences at the time were directed towards experiencing Björk's role as a form of self-presentation, since she was not only a famous musician but also sings and dances in the film, that is, performed as a musician. Meanwhile, the critical discourse surrounding the film tended to deny her identity as an actor and so denied the performance any overtly fictional character. In what follows, I employ this conceptual framework to show how in fact Dancer gave Björk the opportunity to perform her musical persona through the film's character of Selma and so integrate her image as an emotionally authentic artist.

\section{Björk versus Selma: The Construction of Selma's Filmic Character and the Quest for Authenticity}

Auslander claims that genres are sets of constraints on constructing the personae of performance, since genres constitute themselves as social frames with particular conventions: "musical genres are Goffmanian frames that contextualize the expectations surrounding the mutual self-presentations of musicians and their audiences" (2015a: 69-70; see also 2006: 105-106; 2009: 306-309). In The American Film Musical, Rick Altman clarifies this relationship between genre and persona:

more than in any other genre, the musical calls on actors to play themselves. Thus Chevalier plays the song-and-dance-man Chevalier, Astaire plays the elegant top-hat-white-tie-and-tails Astaire, and Kelly plays the familiar happygo-lucky self-confident Kelly. As viewers, we rarely have to deal with a 
contradiction between actor and character, thus reducing the gap separating fiction and reality, and with it the spectator's psychic expenditure. (Altman 1987: 80).

So in a film musical, actors normally do not portray overtly fictional characters in their performances, but rather perform personae in tune with their images. Dancer reinforces this type of interpretive reading (for an analysis of Dancer with regard to the musical traditions of the film genre, see Heldt 2013: 162-170). The fundamental difference between Björk and Gene Kelly, however, is that Kelly was viewed less as an artist than as an entertainer (cf. Cohan 2005: 149-199). For the singersongwriter concept, authenticity and authorship have developed into important aesthetic categories (see Barker and Taylor 2007: 101-134; Negus 2011: 623). Björk's authorial image altered her reception by suggesting an interpretation of her music in terms of her biography, and intuitive perceptions of her music as emotionally authentic. Lars von Trier's and Björk's previously quoted statements about her acting underscore how Björk did not seek to portray an overtly fictional character, but rather claimed to perform her persona directly. According to Richard Dyer (2012: 86), authenticity is "established or constructed in media texts by the use of markers that indicate lack of control, lack of premeditation and privacy." As we have seen, the discourse surrounding the film emphasized the spontaneous, immediate, and private nature of her performance.

So, who is this Björk who presents herself? In the musical within the melodrama (Selma's imagination), Björk performs a musical persona. Although external Selma and Björk share attributes of being child-like or vulnerable, the similarities between the two musical personae prove all the more striking. In comparing the appearance and manner of Selma's fantasy double in Dancer with Björk in "It's Oh So Quiet," we see that they not only share social markers such as sex, age, and racial characteristics, but also a number of other visual similarities. Björk's and Selma's vocabularies converge upon one another: whether movement (tap dance), costuming (colorful shift dresses cut with jewel necklines and short sleeves), the lack of visible make-up, facial expressions including childish smiles with closed eyes, with their head posed upturned to the sky (dir. von Trier 2000: 0.54.55; dir. Jonze 1995: 3.38), or the slightly over-miked voice, which reinforces the impression of an intimate interpersonal relationship by dint of the audibly close distance. Due to the personal front and the setting, the musical sequences in Dancer seem intended to frame themselves as possible music videos for Björk. All these aspects cause the performed entity to take on the likeness of the performer and her persona rather than the character, giving the impression that "Björk performs Björk" (Tate 2000). "In one sense," as Britta Sjogren aptly states, "the musical scenes convey Selma's fantasy that she is Björk" (2006: 191; emphasis Sjogren's). In other words, Björk portrays a character who dreams of being Björk.

Since our perception of the film is mediated by our conception of the performer's image, Björk's musical persona rubs off on the filmic musical persona, and so intensifies the impression of Selma as an authentic character. Performing simultaneously as musician and composer supports this intimate aspect of authenticity. Björk addresses this bilaterally: the character of Selma composes the songs, as she dreams them up in her fantasy world, and the popstar Björk composes the songs quite literally, releasing them as her album Selmasongs (One Little Indian Records 2000) and including some of them in her stage programs (such as her recorded performance on 7 December 2001 at the Royal Opera House, London). 
Even more than that, Björk's musical persona is located in Selma's intimacy. Although Selma and Björk at the time portrayed shared attributes of child-like innocence or vulnerability, the external strata of Selma clarifies that the film is not a biopic of Björk. During the musical performances however, Selma becomes a part of Björk's musical persona since she also performs a fictional entity through the song lyrics, namely, the musical character of Selma. As shown in Figure 1, the musical performances interlock Björk's musical persona with Selma's character: Selma's dream double offers Björk the context to perform her musical persona directly, while simultaneously this persona mediates between performer (Björk) and character (Selma), constituting a Björk-as-Selma/Selma-as-Björk nexus. Utilizing Moore's (2002) typology for the construction of authenticity, this nexus corresponds to his "third person authenticity" ("authenticity of execution") as well as "first person authenticity" ("authenticity of expression"). Whereas the former arises "when a performer succeeds in conveying the impression of accurately representing the ideas of another" (ibid.: 218), the latter occurs "when an originator (composer, performer) succeeds in conveying the impression that his/her utterance is one of integrity, that it represents an attempt to communicate in an unmediated form" (ibid.: 214). We can therefore interpret Björk's performance to convey that "this is what it is like to be Selma" and "this is what it is like to be me" at the same time: for Selma is a part of Björk (Selma's character in Björk's musical performance) but Björk is also a part of Selma (Björk's musical persona in Selma's imagination).

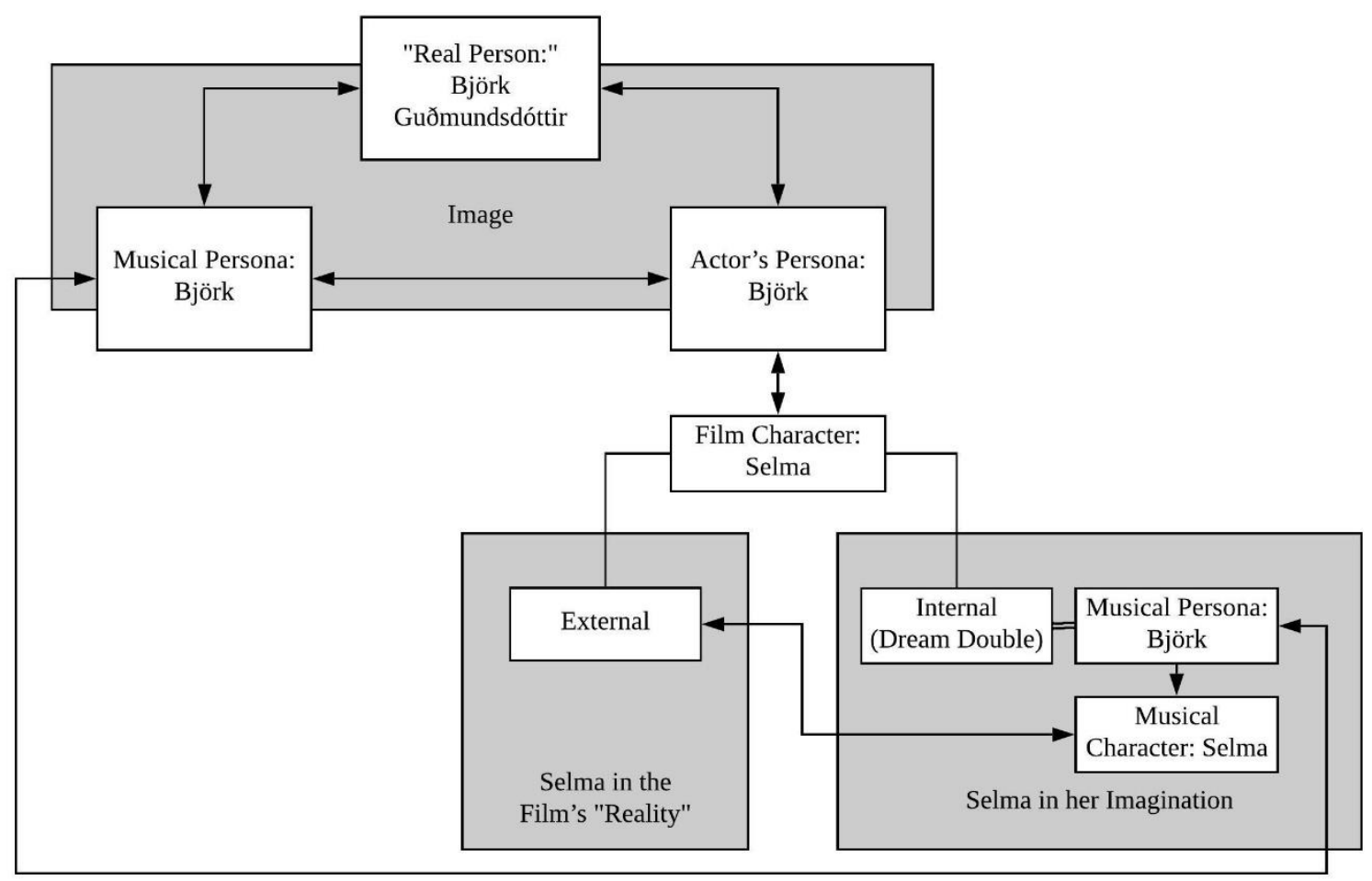

FIGURE 1. The construction of Björk's performance in Dancer in the Dark.

"Was it even a performance?" Badley asks (2010: 98). From my point of view, Björk's Selma was a performance that seems to undermine its status as a performance due to its construction. The impression of Björk's acting performance as a presentation of 'authentic' self arises through the construction of the film character, as it affords Björk the context to perform simultaneously her musical 
persona and Selma in the film character's inner world. The collapsing "borders between reality and simulation" (Badley 2010: 98-99) apply primarily to the borders between Björk's musical persona and the musical performances in the film, but since Björk's musical persona was perceived as emotionally authentic, and Selma forms part of Björk's performance for her musical persona within Dancer, Björk and Selma authenticate one another simultaneously. The film's "simulation" appears to become reality.

\title{
Empathy versus (?) Escape
}

Maria Cizmic (2015) claims that von Trier's use of pre-existing rock music in his film Breaking the Waves (1996) shows "how empathy and escape, pleasure and suffering can become entangled in a morally complex embrace" (ibid.: 1). Cizmic follows Vivian Sobchack's phenomenological approach, which suggests that watching film produces responses that engage the viewer's knowledge regarding their physically lived experiences (cf. Sobchack 2004: 53-84). "The images and sounds on screen," as Cizmic reads Sobchack, "trigger knowledge about how an experience might feel upon the body, or taste on the tongue, or impact upon [an] individual's sense of gravity, weight, and movement" (2015: 4). In Breaking, the use of 1970s rock "develops a physical empathy between the viewer and Bess [the main character], encouraging others to imagine in their own bodies what Bess experiences in the film" (ibid.: 5). Yet as Bess's circumstances spiral out of control, the music sounding at the fore of each chapter heading opens up "a space of musical escape from the film's downward spiral" (ibid.: 18) since it "prompt[s] audiences to focus more awareness on their physical, and emotional response to the music" (ibid.: 17). Thus, the use of music in Breaking pulls the audience between two states: "an embodied identification with Bess and an awareness of one's own physical responses to music separate from Bess" (ibid.: 1). "At the same time that a viewer can empathise with Bess," Cizmic (ibid.: 22) argues, "such a person can have his or her own personal experiences; at the same time that Bess suffers, a viewer can enjoy a bit of musical pleasure." In this sense, von Trier attempts to provoke spectators to reconsider their engagement with the film (cf. Bainbridge 2003 and 2004):

\begin{abstract}
Von Trier's use of music encourages an audience member to relate to Bess in an embodied manner while never letting one lose a sense of one's own body as distinct from the film. This musically constructed position raises what I think is one of the central ethical questions of our own historical and cultural moment: how do we relate to representations of someone else's suffering? (Cizmic 2015: 27).
\end{abstract}

The integration of Björk and her music into Dancer functions in much the same way. Björk's music may lead the audience towards sharing a feeling of empathy with Selma. But while Selma's circumstances spiral out of control, the film leaves space for our responses to her music to function as a form of escape. When we see Selma dancing and singing on the way to her execution in "107 Steps," the musical number reminds us that what we actually see is the popstar Björk's performance. Since the numbers are long enough to disconnect from the film's narrative and shift focus from the film to the song's performance, the musical interludes appear to create a space for the audience independent of Selma's tragedy. Apart from casting a pop musician, one difference that separates Dancer from paralleling Breaking is 
how Selma herself enjoys musical pleasure during her daydreams, even on her way to execution. Therefore, the music pulls the audience equally between two states: an identification with Selma and an awareness of one's own experience with Björk. Since the audience shares the space for escapism with Selma, the integration of Björk and the construction of Selma's character highlight even more than in Breaking how pleasure and suffering, empathy and escape can become tangled in moral complexity. Are we supposed to pass judgement on the characters and events, as if they were real? Or are we intended to recognize that the film pulls us in as close as possible to Selma only to remind us that the true fiction is our very perception of closeness? The polarized reception of the film suggests that Lars von Trier and Björk's performance place the onus on the audience to create meaning.

In the final sequence, Selma waits on the gallows for her execution. As Selma's dream world finally disintegrates completely, she sings her last number "Next To Last Song" without brighter colors, static cameras, stereophonic music, a dubbed voice or any background musical activity. In her study about the female voice in cinema, Sjogren (2006: 195) interprets this unmediated sound of her voice as a "final 'pinning' of Björk's voice to Selma's body." But who do we see here? Who is on the gallows: Björk, suffering while playing Selma, or Selma played by Björk, or both? In the screenplay, von Trier describes the scene as follows:
Selma moves into the song with complete confidence. Happy and exalted as never before! She makes up the song as she sings it with great pleasure. This song is filmed both in the same way as the other dance numbers, with many fixed cameras, and with the traditional handle camera. When we are in the fixed camera state, everybody in the room seems to have frozen and does not move much. In the handle camera state, Brenda's argument with the officials still goes on, as does the other chaotic action. (von Trier 2000: 150-151).

According to the script, a simultaneity of dream world and fictional reality was planned, whereas the final film denies the audience the escape into Selma's musical world. Yet this presentation still offers a measure of equivocation, in that the scene does not readily resolve in its entirety through either a wholly realistic or fictive reading. The simultaneity expressed through cross-cutting as described in the script would still distinguish clearly between these two levels. On the contrary, the lack of this distinction results in the impression that the character of Selma and Björk's musical persona merge completely: Björk in Selma's dream and Selma in Björk's performance. We see and hear Björk singing, recorded live on the film set rather than dubbed, and without playback or musical accompaniment. Björk meanwhile engages in "dramatization," (Auslander 2006: 112) or making visible through her performance the work demanded of the performer, so that an "idealized image of the musician as emotionally expressive is conveyed (...) that purport[s] to expose the musician's internal state while performing" (ibid.). Her effort is audible in her limited intonation errors, the clarity of vocal articulation, intimately highlighted non-musical vocal sounds (including sharp intakes of breath), her amplified heartbeat and a dynamic range from fragile piano to vigorous forte. Likewise, she makes her efforts visible through her crouched pose and facial expressions ranging from agony to a childish smile, the latter intensified by extreme close-ups. In contrast to the version of this song for Selmasongs (also heard over the ending credits), the lyrics she sings on the gallows are - for the first time - explicitly anchored in the narrative. She addresses her (absent) son Gene and refers back to a moment together near the film's beginning. It is only in the final moment when 
Björk's musical persona and Selma's character assert the same degree of visibility at the same time. The persona seems to become indistinguishable from character and the performance comes close to being a pure presentation of persona rather than a representation of a character.

Lars von Trier's use of music and the integration of Björk's persona therefore raise important ethical questions: how do we as an audience relate to (re)presentations of someone else's suffering? How do we relate to (re)presentations of (self-?)sacrifice by a person we believe to know? Lars von Trier said that what he wanted to achieve for the viewer of Dancer is

that you take things as seriously as you do in an opera. Some years ago, people really cried at operas. I think it's a skill to be able to find such an emotion in something so stylised. I would love to feel that much for someone who's been killed with a cardboard sword. (von Trier 2000: vi).

Indeed, individual responses to the film vary considerably depending on one's knowledge of or affinity with Björk in addition to their cultural background. What this study reveals through the analysis of Björk/Selma, though, is the heightened potential for exploring our own engagement with concepts of fiction when we actively confront such performances by popstars on film. Although von Trier's "cardboard sword" certainly remains a prop, my analysis expands our understanding of why some props still seem incredibly real to us.

\section{Endnotes}

(1) The final version slightly shortens this dialogue compared to von Trier's published screenplay (cf. dir. von Trier 2000: 0.03.55). This and the following time codes refer to the DVD edition by Zentropa Entertainment (2001), see videography below.

(2) Björk's transformation can be seen in her album artwork. Similar to the artwork for Debut, most covers show Björk in a medium or shoulder-height close-up portrait (including Selmasongs), while her appearance changed extremely (see Gibsone 2015).

(3) Years later, as part of the \#MeToo movement, Björk published a Facebook post in which she alleged that von Trier sexually harassed her on set (see Björk 2017).

(4) While I acknowledge the shifting landscape of communication between stars and fans as a result of social media, this complication lies beyond the scope of the current study. I suggest only that, for audiences encountering Dancer at the turn of the millennium, Auslander's model accurately describes the relationships undergirding their reception aesthetics. For more on pop personae as transmedial phenomena, see Hansen (2019).

\section{Acknowledgements}

I am grateful to Christian Thorau, Steffen Just, Daniel Suer, Oren Vinogradov, and the reviewers at IASPM Journal for their thoughtful suggestions and critical feedback on this paper.

\section{References}

\section{Bibliography}

Ago, A. 2003. Once Upon a Time in Amerika: Dancer in the Dark and

Contemporary European Cinema. Spectator 23 (2): 32-43. 
Altman, R. 1987. The American Film Musical. Bloomington and Indianapolis: Indiana University Press.

Aston, M. 1996. Björk: Björkgraphy. London: Schuster \& Schuster.

Auslander, P. -

1992. Presence and Resistance: Postmodernism and Cultural Politics in

Contemporary American Performance. Ann Arbor: University of Michigan Press.

2002[1986]. Just Be Your Self: Logocentrism and Difference in Performance

Theory. In P. B. Zarrilli Ed. Acting (Re)Considered: A Theoretical and

Practical Guide. London and New York: Routledge: 53-60.

2004. Performance Analysis and Popular Music: A Manifesto. Contemporary

Theatre Review 14 (1): 1-13.

2006. Musical Personae. The Drama Review 50 (1): 100-119.

2009. Musical Persona: The Physical Performance of Popular Music. In D. B.

Scott Ed. The Ashgate Research Companion to Popular Musicology.

Farnham: Ashgate Publishing: 303-315.

2015a. On the Concept of Persona in Performance. Kunstlicht 36 (3): 62-79.

2015b. Everybody's in Show Biz: Performing Star Identity in Popular Music. In

A. Bennett and S. Waksman Eds. The Sage Handbook of Popular Music. Los Angeles and London: Sage: 317-331.

Badley, L. 2010. Lars von Trier: Contemporary Film Directors. Urbana, Chicago and Springfield: University of Illinois Press.

Bainbridge, C. -

2003. Making Waves: Trauma and Ethics in the Work of Lars von Trier. Journal for Cultural Research 8 (3): 353-370.

2004. The Trauma Debate: Just Looking? Traumatic Affect, Film Form and Spectatorship in the Work of Lars von Trier. Screen 45 (4): 391-400.

Barker, H. and Y. Taylor. 2007. Faking it: The Quest for Authenticity in Popular Music. New York and London: W.W. Norton \& Company.

Björk. -

2000. Why she decided to act. Webchat, 22 June, archived 22 December 2007. Available from:

https://web.archive.org/web/20071222180117/http://www.bjork.com/facts/a bout/right.php?id=629. Accessed: 21 November 2019.

2017. Facebook, 15 October. Available from:

https://www.facebook.com/bjork/posts/i-am-inspired-by-the-women-

everywhere-who-are-speaking-up-online-to-tell-aboutm/10155777444371460/. Accessed: 18 August 2020.

Björkman, S. 2001. Trier über von Trier: Gespräche mit Stig Björkman. Hamburg: Rogner \& Bernhard.

Borgstedt, S. 2008. Der Musik-Star. Vergleichende Imageanalysen von Alfred Brendel, Stefanie Hertel und Robbie Williams. Bielefeld: Transcript.

Cizmic, M. 2015. The Vicissitudes of Listening: Music, Empathy, and Escape in Lars von Trier's Breaking the Waves. Music, Sound, and the Moving Image 9 (1): $1-32$.

Cohan, S. 2005. Incongruous Entertainment: Camp Cultural Value, and the MGM Musical. Durham and London: Duke University Press.

Cooke, M. 2008. A History of Film Music. Cambridge: Cambridge University Press. 
Daston, L. and O. H. Sibum. 2003. Scientific Personae and Their Histories. Science in Context 16 (1/2): 1-8.

Dibben, N. -

2006. Subjectivity and the Construction of Emotion in the Music of Björk.

Music Analysis 25 (1/2): 171-197.

2009. Björk. London: Equinox Publishing.

Dyer, R. 2012. In the Space of a Song: The Uses of Song in Film. New York: Routledge.

Elbeshlawy, A. 2016. Woman in Lars von Trier's Cinema. 1996-2014. Cham: Palgrave Macmillan.

Foucault, M. 1977. What is an Author? [1969] In D. Bouchard Ed. Language, Counter-Memory, Practice. Ithaca, New York: Cornell University Press: 113138.

Frith, S. 1996. Performing Rites: On the Value of Popular Music. Cambridge, Mass: Harvard University Press.

Gibsone, H. 2015. Björk's Album Artwork: from Sci-Fi Mother Earth to McQueen's Kimono - in Pictures. The Guardian, 22 January. https://www.theguardian.com/music/gallery/2015/jan/22/bjorks-album-artworkin-pictures-vulnicura-biophilia. Accessed: 21 November 2019.

Goffman, E. 1956. The Presentation of Self in Everyday Life. Edinburgh: University of Edinburgh Social Sciences Research Centre.

Gledhill, C. 1991. Signs of Melodrama. In C. Gledhill Ed. Stardom: Industry of Desire. London: Routledge: 206-229.

Graver, D. 1997. The Actor's Bodies. Text and Performance Quarterly 17 (3): 221-235.

Grimley, D. M. 2005. Hidden Places: Hyper-realism in Björk's Vespertine and Dancer in the Dark. Twentieth-Century Music 2 (1): 37-51.

Grissemann, S. 2006. Torture is Fine: Lars von Trier Interview. Film Comment, January-February. https://www.filmcomment.com/article/lars-von-trierinterview-manderlay/. Accessed: 25 January 2018.

Grodal, T. 2004. Frozen Flows in von Trier's Oeuvre. In T. Grodal, B. Larsen and I. T. Laursen Eds. Visual Authorship, Creativity and Intentionality in Media. Copenhagen: Museum Tusculanum Press: 129-167.

Hansen, K. A. 2019. (Re)Reading Pop Personae: A Transmedial Approach to Studying the Multiple Construction of Artist Identities. Twentieth-Century Music 16 (3): 501-529.

Heath, C. 2011. Lars and his Real Girls. GQ, 17 October. https://www.gq.com/story/lars-von-trier-gq-interview-bjork-john-c-reilly-kirstendunst-nicole-kidman-extras. Accessed: 21 November 2019.

Heldt, G. 2013. Music and Levels of Narration in Film: Steps Across the Border. Bristol and Chicago: Intellect.

Hilderbrand, L. 2000. Dancer in the Dark, Les Miserables, or, It's Oh So Björk. PopMatters, July. https://www.popmatters.com/dancer-in-the-dark/. Accessed: 1 November 2019.

Jacke, C. 2013. Inszenierte Authentizität versus authentische Inszenierung: ein Ordnungsversuch zum Konzept Authentizität in Medienkultur und Popmusik. In D. Helms and T. Phleps Eds. Ware Inszenierungen. Bielefeld: Transcript (Beiträge zur Popularmusikforschung, 39): 71-95. 
Kaufman, A. 2003. Lars von Trier Comes Out of the Dark. In J. Lumholdt Ed. Lars von Trier Interviews. Jackson: University Press of Mississippi: 153-158.

Keazor, H. and T. Wübbena. 2007. Video thrills the Radio Star. Musikvideos: Geschichte, Themen, Analysen. Bielefeld: Transcript.

Koplev, K. 2003. 9 a.m., Thursday, September 7, 2000: Lars von Trier. In J. Lumholdt Ed. Lars von Trier Interviews. Jackson: University Press of Mississippi: 170-204.

Leonard, M. 2007. Gender in the Music Industry: Rock, Discourse and Girl Power. Aldershot: Ashgate (Ashgate Popular and Folk Music Series).

Lössl, U. 2000. Interview mit Lars von Trier: Björk wollte nicht erhängt werden. Der Spiegel, 28 September. http://www.spiegel.de/kultur/kino/interview-mitlars-von-trier-bjoerk-wollte-nicht-erhaengt-werden-a-95723.html. Accessed: 25 January 2018.

Meyers, E. 2009. "Can You Handle My Truth?": Authenticity and the Celebrity Star Image. The Journal of Popular Culture 42 (5): 890-907.

Moore, A. -

2002. Authenticity as Authentication. Popular Music 21 (2): 209-223.

2012. Addressing the Persona. In D. Helms and T. Phleps Eds. Black Box Pop: Analysen Populärer Musik. Bielefeld: Transcript (Beiträge zur Popularmusikforschung, 38): 125-133.

Morin, E. 1960. The Stars: An Account of the Star-System in Motion Pictures [1957]. Translated by Richard Howard. New York: Grove Press.

Negus, K. 2011. Authorship and the Popular Song. Music \& Letters 92 (4): 607629.

O'Sullivan, C. 2000. Love, hate and rows with Bjork. Independent, 25 August. http://www.independent.co.uk/arts-entertainment/films/features/love-hate-androws-with-bjork-697347.html. Accessed: 25 January 2018.

Pisters, P. 2003. The Matrix of Visual Culture: Working with Deleuze in Film Theory. Stanford: Stanford University Press.

Plessner, H. (1982). Zur Anthropologie des Schauspielers [1948]. In Ausdruck und menschliche Natur: Gesammelte Schriften VII. Frankfurt am Main: Suhrkamp: 205-219.

Pytlik, M. 2003. Björk: Wow and Flutter. Toronto: ECW Press.

Reckwitz, A. 2019. Die Erfindung der Kreativität: Zum Prozess gesellschaftlicher Ästhetisierung [2012]. Berlin: Suhrkamp.

Reese, L. 2000. Björk explains the conflict over "Selmasongs." Entertainment Weekly, 31 October. https://ew.com/article/2000/10/31/bjork-explains-conflictover-selmasongs/. Accessed: 19 January 2020.

Rosenbaum, J. 2000. Doing the Hustle [Dancer in the Dark]. Chicago Reader, 27 October. http://www.jonathanrosenbaum.net/2020/03/doing-the-hustle/. Accessed: 25 January 2018.

Rosiny, C. 2013. Tanz Film: Intermediale Beziehungen zwischen Mediengeschichte und moderner Tanzästhetik. Bielefeld: Transcript.

Sjogren, B. 2006. Into the Vortex: Female Voice and Paradox in Film. Urbana and Chicago: University of Illinois Press.

Sobchack, V. 2004. Carnal Thoughts: Embodiment and Moving Image Culture. Berkeley, Los Angeles and London: University of California Press.

Stevenson, J. 2002. Lars von Trier. London: BFI Publishing. 
Tate, G. 2000. Björk's Second Act. Paper, 1 October. http://www.papermag.com/bjorks-second-act-1425145050.html. Accessed: 25 January 2018.

Tiefenbach, G. 2010. Drama und Regie: Lars von Trier's Breaking the Waves, Dancer in the Dark, Dogville. Würzburg: Königshausen \& Neumann. von Trier, L. 2000. Dancer in the Dark. London, Basingstoke and Oxford: Filmfour Screenplay/Macmillan Publishers.

2001. Das Selma-Manifest. In S. Björkman Ed. Trier über von Trier: Gespräche mit Stig Björkman. Hamburg: Rogner \& Bernhard: 247-250.

Winters, B. 2014. Music, Performance, and the Realities of Film: Shared Concert Experience in Screen Fiction. New York and London: Routledge.

\section{Discography}

Betty Hutton. 1951. "It's Oh So Quiet," Murder, He Says, RCA.

Björk. -

1977. Björk, Fálkinn Records.

1993. Debut, One Little Indian Records.

2000. Selmasongs: Music from the Motion Picture Soundtrack "Dancer in the

Dark," One Little Indian Records.

2001. Vespertine, One Little Indian Records.

Horst Winter. 1948. "Und jetzt ist es still," Austroton.

\section{Videography}

Films

Breaking the Waves. 1996. Dir. Lars von Trier, Trust Film et al.

Dancer in the Dark. 2000. Dir. Lars von Trier, Zentropa et al.

Drawing Restraint 9. 2005. Dir. Matthew Barney, Restraint LLC.

Glerbrot. 1987. Dir. Kristín Jóhannesdóttir, Rúv.

Les Parapluies de Cherbourg. 1964. Dir. Jacques Demy, Parc Film et al.

The Juniper Tree. 1990. Dir. Nietzchka Keene, Rhino.

\section{Music Videos}

Hidden Place. 2001. Björk. Dir. Inez van Lamsweerde and Vinoodh Matadin, One Little Indian Records.

It's Oh So Quiet. 1995. Björk. Dir. Spike Jonze, One Little Indian Records.

\section{DVDs}

Dancer in the Dark. 2000. Dir. Lars von Trier. DVD. Zentropa et al., 2001.

The Work of Director Spike Jonze. A Collection of Music Videos, Short Films, Documentaries, and Rarities. 2003. Dir. Spike Jonze. DVD. Palm Pictures. 